\title{
Methodology of Defining of the Radiation Therapy Components for Various Methods of Patients' Treating Using Medical Linear Accelerators and Gamma-Therapeutic Devices
}

\author{
E.V. Titovich, M.N. Piatkevich, N.I. Makarava \\ N.N. Alexandrov National Cancer Centre of Belarus, \\ Lesnoy 223040, Minsk District, Belarus
}

Received 24.02.2020

Accepted for publication 21.10.2020

\begin{abstract}
One of the main factors affecting the effectiveness of radiation therapy is the constancy of the patient's position on the treatment table created by immobilization devices of various designs and held throughout the entire irradiation procedure, which guarantees the accuracy of the delivery of the prescribed dose distribution. The purpose of the work was to establish the numerical values of the dominant components of a radiation therapy session for each of the irradiation techniques most commonly used in clinical practice of the radiation therapy.

To determine the numerical values of the components of the radiation therapy session, the authors have measured each component for some clinical cases of patients' irradiation placed. The patients had been diagnosed with the following malignant tumours: prostate cancer, breast cancer, lung cancer, head and neck tumours. More than 2000 individual measurements have been carried out with the help of such medical linear accelerators as "Clinac", "Unique", "Truebeam", and the gamma-therapeutic apparatus named "Theratron".

The numerical values of the time spent on 3 groups of parameters of an irradiation session were established: the mechanical parameters of the radiation therapy equipment, the functional characteristics of the irradiation systems and the parameters that directly depend on the personnel involved in an irradiation procedure.

According to the measurement results, the flow diagram for the procedures of verifying a patient's position on the therapeutic table ( 2 different techniques), preceding their irradiation and the radiation therapy procedures themselves was proposed. It has been shown that a number of session components can run in parallel to each other thus optimizing the time spent by a patient in the treatment room.

Using the obtained values of the time spent on the radiation session parameters it is possible to actualize the mathematical model that will allow the medical physicist to determine in advance the duration of the irradiation session at the stage of treatment planning and choose a radiation therapy technique taking into account the individual parameters of the irradiation session in each particular clinical case.
\end{abstract}

Keywords: treatment session, linear accelerator, radiation therapy, timing.

DOI: $10.21122 / 2220-9506-2020-11-4-289-297$

\begin{tabular}{ll}
\hline Адрес для переписки: & Address for correspondence: \\
М.Н. Петкевич & M.N. Piatkevich \\
РНПЦ онкологии и медицинской радиологии & N.N. Alexandrov National Cancer Centre of Belarus, \\
имени Н.Н. Александрова, & Lesnoy 223040, Minsk District, Belarus \\
агрогородок Лесной 223040, Минский район, Беларусь & e-mail: MaxPetkevichN@gmail.com \\
e-таil: МахРеtkеvichN@gmail.com & \\
\hline Для цитирования: & For citation: \\
E.V. Titovich, M.N. Piatkevich, N.I. Makarava. & E.V. Titovich, M.N. Piatkevich, N.I. Makarava. \\
Methodology of Defining of the Radiation Therapy Components & Methodology of Defining of the Radiation Therapy Components \\
for Various Methods of Patients' Treating Using Medical Linear & for Various Methods of Patients' Treating Using Medical Linear \\
Aсcelerators and Gamma-Therapeutic Devices. & Accelerators and Gamma-Therapeutic Devices. \\
Приборы и методы измерений. & Devices and Methods of Measurements. \\
2020. - Т. 11, № 4.- C. 289-297. & 2020, vol. 11, no. 4, pp. 289-297. \\
DOI: $10.21122 / 2220-9506-2020-11-4-289-297$ & DOI: 10.21122/2220-9506-2020-11-4-289-297 \\
\hline
\end{tabular}




\title{
Методика определения характеристик компонентов сеанса лучевой терапии для различных методов облучения онкологических пациентов с использованием медицинских линейных ускорителей и гамма-терапевтических аппаратов
}

\author{
Е.В. Титович, М.Н. Петкевич, А.И. Макарова \\ РНПЦ онкологии и медицинской радиологии имени Н.Н. Александрова, \\ агрогородок Лесной 223040, Минский район, Беларусь
}

Поступила 24.02.2020

Принята к печати 21.10.2020

Одним из основных факторов, влияющих на эффективность лучевой терапии является соблюдение постоянства положения пациента на лечебном столе с использованием фиксирующих приспособлений различных конструкций на протяжении всей процедуры их облучения, что гарантирует точность доставки предписанной дозы излучения. Цель работы - установление численных величин доминирующих компонентов сеанса лучевой терапии для каждой из методик облучения, наиболее применяемых в клинической практике лучевой терапии.

Для установления численных величин компонентов сеанса лучевой терапии авторами проведены экспериментальные измерения каждого из них для некоторых клинических случаев облучения пациентов с локализациями злокачественных новообразований: рак предстательной железы, рак молочной железы, рак легкого, опухоли головы и шеи (более 2000 индивидуальных измерений), осуществляемых с использованием медицинских линейных ускорителей следующих моделей: «Clinac», «Unique», «Truebeam», а также гамма-терапевтического аппарата «Theratron».

Установлены численные значения затрачиваемого времени для 3-х групп параметров сеанса облучения: механические параметры аппаратов лучевой терапии, функциональные характеристики систем реализации облучения и параметры, напрямую зависящие от персонала, участвующего в проведении процедуры облучения.

Предложена блок-схема для процедур верификации положения пациента на терапевтическом столе (две различные методики), предшествующей облучению пациента и непосредственно процедурам лучевой терапии. Показано, что ряд компонентов сеанса может осуществляться параллельно друг другу, за счёт чего время, проводимое пациентом в процедурном помещении, может быть оптимизированно.

С использованием полученных значений затрачиваемого времени для параметров сеанса облучения возможна реализация математической модели, которая позволит предварительно определить длительность сеанса облучения на этапе предлучевой подготовки и выбрать методику лучевой терапии с учетом индивидуальных параметров облучения в каждом конкретном клиническом случае.

Ключевые слова: сеанс облучения, линейный ускоритель, лучевая терапия, временные характеристики.

DOI: $10.21122 / 2220-9506-2020-11-4-289-297$

\begin{tabular}{l}
\hline Адрес для переписки: \\
М.Н. Петкевич \\
РНПЦ онкологии и медицинской радиологии \\
имени Н.Н. Александрова, \\
агрогородок Лесной 223040, Минский район, Беларусь \\
е-таil: МахРеtkеvichN@gтаil.сот \\
\hline Для цитирования: \\
E.V. Titovich, M.N. Piatkevich, N.I. Makarava. \\
Methodology of Defining of the Radiation Therapy Components \\
for Various Methods of Patients' Treating Using Medical Linear \\
Accelerators and Gamma-Therapeutic Devices. \\
Приборы и методы измерений. \\
2020. - Т. 11, № 4. - C. 289-297. \\
DOI: 10.21122/2220-9506-2020-11-4-289-297
\end{tabular}

Address for correspondence:

M.N. Piatkevich

N.N. Alexandrov National Cancer Centre of Belarus,

Lesnoy 223040, Minsk District, Belarus

e-mail: MaxPetkevichN@gmail.com

E.V. Titovich, M.N. Piatkevich, N.I. Makarava.

Methodology of Defining of the Radiation Therapy Components for Various Methods of Patients' Treating Using Medical Linear

Accelerators and Gamma-Therapeutic Devices.

Devices and Methods of Measurements.

2020, vol. 11 , no. 4 , pp. 289-297.

DOI: $10.21122 / 2220-9506-2020-11-4-289-297$ 


\section{Introduction}

Forreceiving radiation therapy(RT)oncological patients' radiation safety, it is necessary to ensure their constancy on the worktable by using fixing devices of a standard design throughout the entire irradiation procedure [1]. In 1976, the International Commission on Radiological Systems (ICRU) presented a recommendation according to which the uncertainty in the delivery of the absorbed dose to the target on any therapeutic apparatus should not exceed $5 \%$ [2]. One of the key factors on which the effectiveness of irradiation depends is the time parameters (time spent by a patient in the treatment room), which directly depend on their position, and, consequently, the accuracy of the delivery of an individual three-dimensional dose distribution [3].

In [4], the authors established the temporal characteristics of the irradiation session components, which have a dominant effect on its duration, and proposed an algorithm that allows to set the duration of cancer patients treatment, depending on the use of various methods of radiation therapy and tumour localization.

The process of modern remote RT includes pre-radiation preparation of the patient, treatment planning, verification of the treatment plan and irradiation with a radiotherapy apparatus.

During the radiation planning stage, the medical physicist creates several treatment plans. The plan that best meets the target coverage criteria and exerts the least dose to nearby organs includes more radiation fields, which significantly increases the duration of a patient's treatment session. The session time is also influenced by the choice of a radiation technique. An increased radiation time can surge the errors in the internal position of the target of radiation due to the biological activity of organs [5]. It should be noted that the treatment selection approach described above does not take into account the timing of the RT session.

The aim of this work was to establish methods for the dominant numerical components of a radiation therapy session for each of the methods of radiation used in the radiation therapy. On the basis of the presented experimental data, the program is presented that determines the duration of the radiation session at the stage of pre-radiation preparation and chooses a radiation therapy technique taking into account the individual parameters of the radiation session in each specific clinical case.

\section{Research results}

To determine the temporal characteristics of the components of the RT session, the authors experimentally established the values of the dominant components of the RT session for each of the most commonly used RT in clinical practice. The measurements for clinical cases of irradiation of patients with localizations of malignant neoplasms: prostate cancer, breast cancer, lung cancer, head and neck tumours were taken [6]. For each patient from the specified sample, dosimetry plans were calculated additionally for the rest of RT techniques used in the clinical practice of radiotherapy departments around the world for these localizations [7]: 3D CRT - threedimensional conformal radiation therapy, IMRT intensity modulated radiation therapy, VMAT sector radiation therapy with volumetric intensity modulation or Gating - radiation therapy with respiratory control. A sample of 100 patients was carried out for each site. The measurements were taken for RT sessions carried out using medical linear accelerators of the following models: "Clinac", "Unique", "Truebeam", as well as the gamma-therapy device named "Theratron".

The authors have divided all components of the RT session into 3 groups: mechanical parameters, functional parameters, and parameters that directly depend on the personnel involved in the irradiation procedure.

Mechanical parameters include those ones, the duration of which is not constant and is associated with the components selected at the factory for the implementation of individual manipulations. They include rotation of the therapy table, the tripod of the radiotherapy apparatus and the collimator. The dependences of the rotation time of the therapy table, tripod and collimator on the setting of the required angles are presented in Figures 1-3, respectively.

The following operations were included in the group of functional parameters: loading the irradiation plan on an operator's computer, checking the irradiation plan for errors in data transmission, initializing of the radiotherapy device with the irradiation parameters relevant to the first treatment field, initializing of the accelerator with the irradiation parameters relevant to the second and subsequent medicinal fields. The duration of these procedures depends on the volume of transmitted and processed information. 


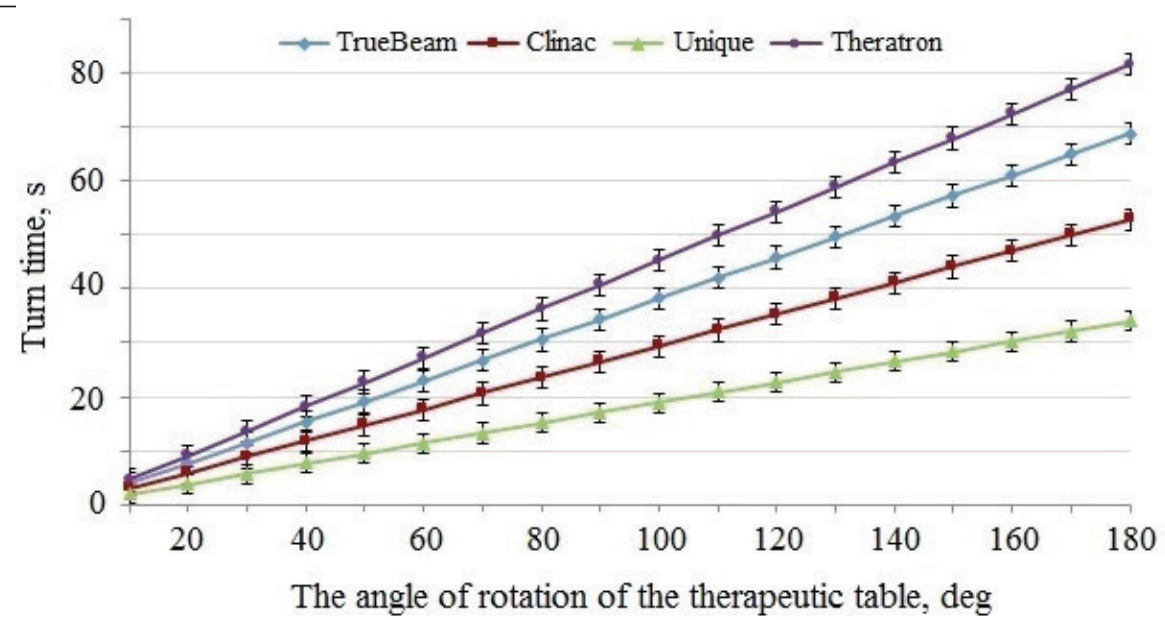

Figure 1 - Dependence of the rotation time of the therapeutic table on the installation of the necessary angles

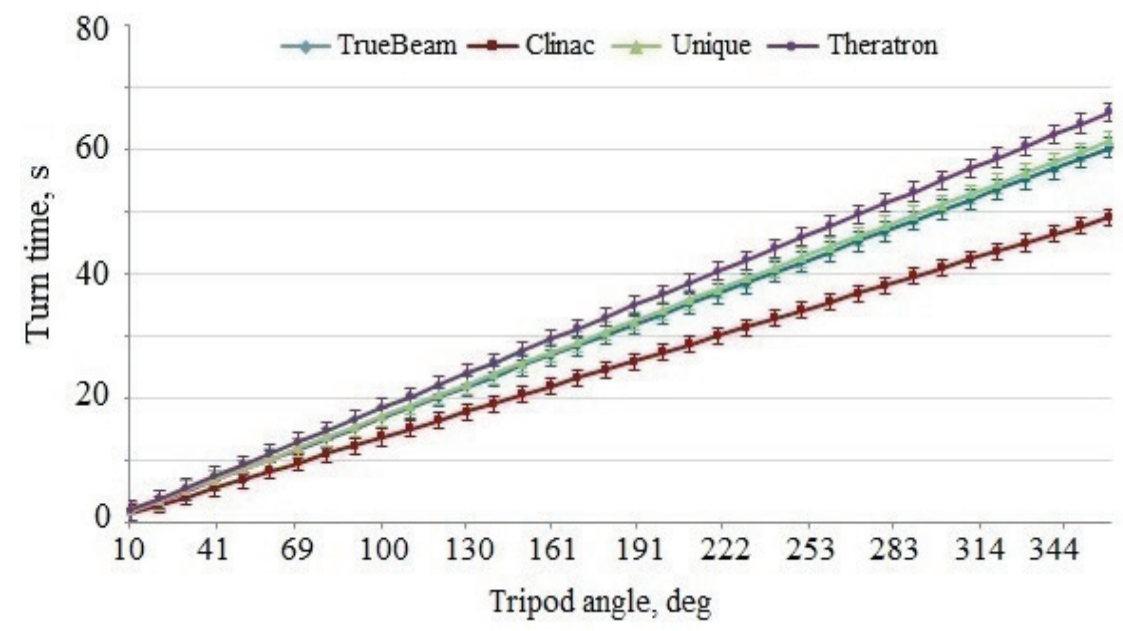

Figure 2 - Dependence of the tripod rotation time on setting the necessary angles

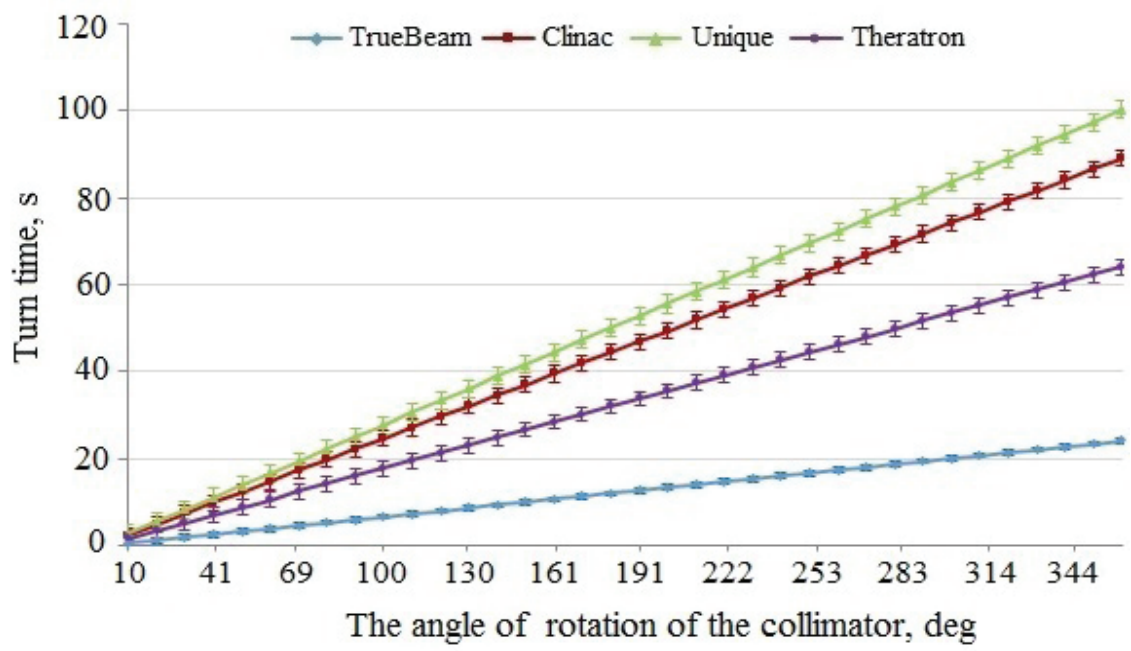

Figure 3 - Dependence of the collimator rotation time on the given angles

The parameters that directly depend on the personnel involved in the irradiation procedure include these operations, the performance of which is entrusted with a person, and rely on the individual characteristics of an individual specialist. These include placing the patient and centering in the prescribed for the irradiation position, entering the irradiation parameters, setting the required mechanical parameters of the accelerator under visual control from the treatment room, installing / 
removing dose modulating devices, switching on the irradiation, and verifying the patient's position [8].
The table shows the measurements of mechanical procedures during the RT session, depending on the radiotherapy device.

Table

Temporal parameters of all procedures during a radiation therapy session, depending on the radiotherapeutic apparatus and localization

Characteristic

Duration of the procedure depending on the radiotherapy device, $\mathrm{s}$

\begin{tabular}{lcccc}
\cline { 2 - 4 } & TrueBeam & Clinac & Unique & Theratron \\
\hline & Duration of mechanical procedures of radiotherapy session \\
\hline $10^{\circ}$ rotation of the therapeutic table & 3.82 & 2.94 & 1.89 & 4.53 \\
Rotate the tripod by $10^{\circ}$ & 1.67 & 1.36 & 1.70 & 1.83 \\
$10^{\circ}$ rotation of the collimator & 0.67 & 2.47 & 2.78 & 1.78
\end{tabular}

The duration of the functional procedures of radiation therapy sessions

Loading the radiation plan on the operator's computer

$8-20 \quad 20 \quad 8-10$

Checking the radiation plan for errors in data transmission

15

10

4-40

10

Initialization of a radiotherapy device with radiation parameters relevant to the

20

4-8

first treatment field

Initialization of the accelerator with radiation parameters relevant to the 6-11 20

$$
\text { 4-45 }
$$

second and subsequent treatment fields

Duration of procedures related to human effort

\begin{tabular}{|c|c|c|c|c|c|}
\hline \multicolumn{2}{|c|}{$\begin{array}{l}\text { Laying the patient and centering in the } \\
\text { prescribed position for irradiation }\end{array}$} & 120 & 120 & $117-176$ & 120 \\
\hline \multicolumn{2}{|c|}{ The input parameters of irradiation } & - & - & - & $20-30$ \\
\hline \multicolumn{2}{|c|}{$\begin{array}{l}\text { Setting the necessary mechanical } \\
\text { parameters of the accelerator under } \\
\text { visual control from the treatment room }\end{array}$} & $50-60$ & 11 & $10-32$ & 11 \\
\hline \multicolumn{2}{|c|}{ Inserting/removing wedge-shaped filters } & - & 40 & 40 & $10-30$ \\
\hline \multicolumn{2}{|c|}{ The inclusion of irradiation } & 5 & 2 & $1-3$ & $2-3$ \\
\hline \multicolumn{2}{|c|}{ Verification of a patient's position } & $40-120$ & - & $20-57$ & 7 \\
\hline \multicolumn{2}{|c|}{$\begin{array}{l}\text { Removing a patient from the treatment } \\
\text { room }\end{array}$} & $55-65$ & $55-65$ & $55-65$ & $55-65$ \\
\hline \multicolumn{6}{|c|}{ The radiation time for patients } \\
\hline \multirow{3}{*}{ Prostate cancer } & 3D CRT & - & $69-220$ & - & - \\
\hline & IMRT & $300-600$ & - & $310-671$ & - \\
\hline & VMAT & 120 & - & $180-300$ & - \\
\hline \multirow{3}{*}{ Breast cancer } & 3D CRT & - & $160-335$ & - & 500 \\
\hline & IMRT & $300-480$ & - & $840-1050$ & - \\
\hline & Gating VMAT & $224-350$ & - & - & - \\
\hline \multirow{3}{*}{ Lung cancer } & 3D CRT & - & $124-451$ & $181-504$ & $163-477$ \\
\hline & IMRT & $365-509$ & - & $321-485$ & - \\
\hline & VMAT & 181 & - & $208-300$ & - \\
\hline
\end{tabular}


Table (continued)

\begin{tabular}{|c|c|c|c|c|c|}
\hline \multirow{2}{*}{ Characteristic } & & \multicolumn{4}{|c|}{ Duration of the procedure depending on the radiotherapy device, $\mathrm{s}$} \\
\hline & & TrueBeam & Clinac & Unique & Theratron \\
\hline \multicolumn{6}{|c|}{ The radiation time for patients } \\
\hline \multirow{3}{*}{$\begin{array}{l}\text { Head and neck } \\
\text { tumours }\end{array}$} & 3D CRT & - & $480-670$ & - & $140-900$ \\
\hline & IMRT & - & - & $360-510$ & - \\
\hline & VMAT & - & - & $270-342$ & - \\
\hline \multicolumn{6}{|c|}{ The session of radiation therapy } \\
\hline \multirow{4}{*}{ Prostate cancer } & 3D CRT & - & $320-420$ & - & - \\
\hline & IMRT & $520-900$ & - & $480-896$ & - \\
\hline & VMAT & 360 & - & $360-480$ & - \\
\hline & 3D CRT & - & $350-512$ & - & 720 \\
\hline \multirow[t]{2}{*}{ Breast cancer } & IMRT & $720-1080$ & - & $990-1200$ & - \\
\hline & Gating VMAT & $840-1020$ & - & - & - \\
\hline \multirow{3}{*}{ Lung cancer } & 3D CRT & - & $248-670$ & $302-625$ & $185-602$ \\
\hline & IMRT & $480-629$ & - & $445-702$ & - \\
\hline & VMAT & 390 & - & $340-420$ & - \\
\hline \multirow{3}{*}{$\begin{array}{l}\text { Head and neck } \\
\text { tumors }\end{array}$} & 3D CRT & - & $720-900$ & - & $260-1020$ \\
\hline & IMRT & - & - & $410-692$ & - \\
\hline & VMAT & - & - & $390-471$ & - \\
\hline
\end{tabular}

The duration of the RT session directly depends on the number of treatment fields of irradiation [9]. Figure 4 shows the dependences of
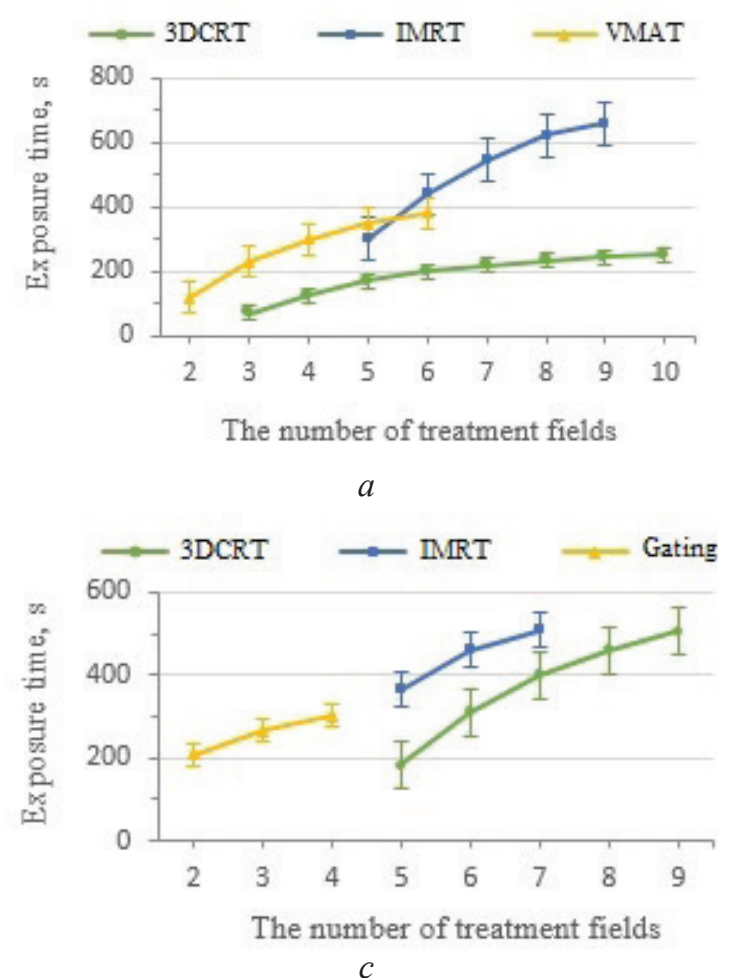

c the radiation time for the considered localizations on the number of irradiation fields for various RT techniques.
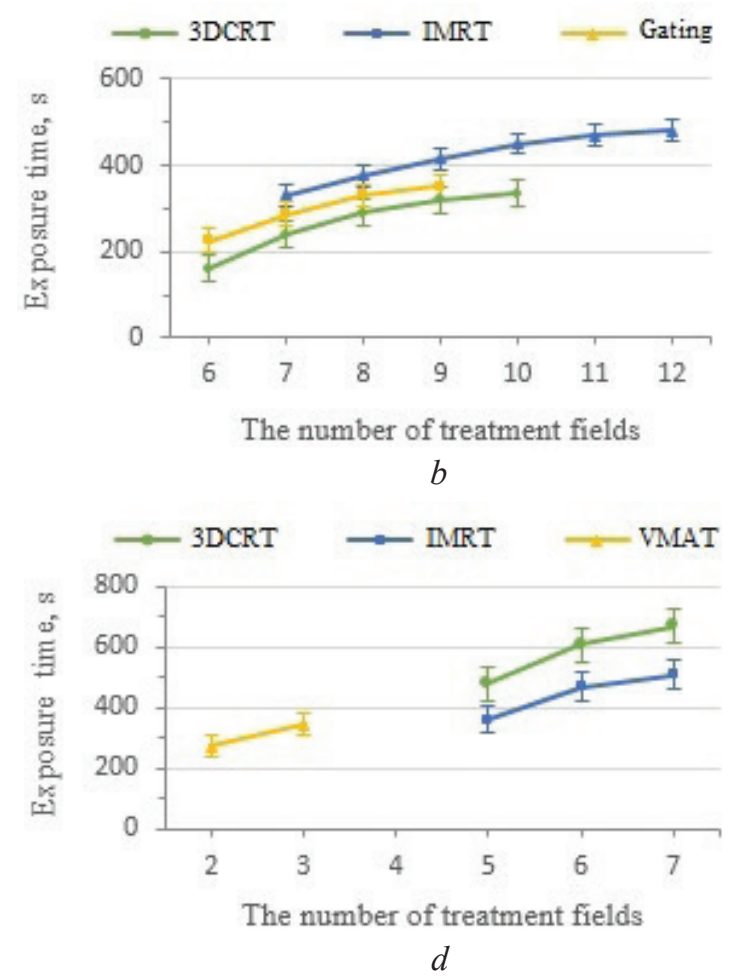

Figure 4 - Dependence of the patient's radiation time on the number of radiation fields for various methods of radiation therapy: $a$ - or patients suffering from prostate cancer; $b$ - for patients with breast cancer; $c$ - for patients suffering from lung cancer; $d$ - for patients with head and neck tumours 


\section{Flow diagram of a typical radiation therapy session}

The RT session on modern radiation devices begins with the verification of the patient's position according to the planned one [10]. Today, the RT uses two types of the patient position verification: $\mathrm{kV}$ and $\mathrm{CBCT}$. During $\mathrm{kV}-$ verification two orthogonal images are taken and then used to compare the patient's position before the RT session in two projections. During CBCT, a volumetric computed tomography is built and comparison is made over the entire volume of tissues covered by the scanned area. Flow diagram of a typical radiation therapy session is shown in Figure 5.

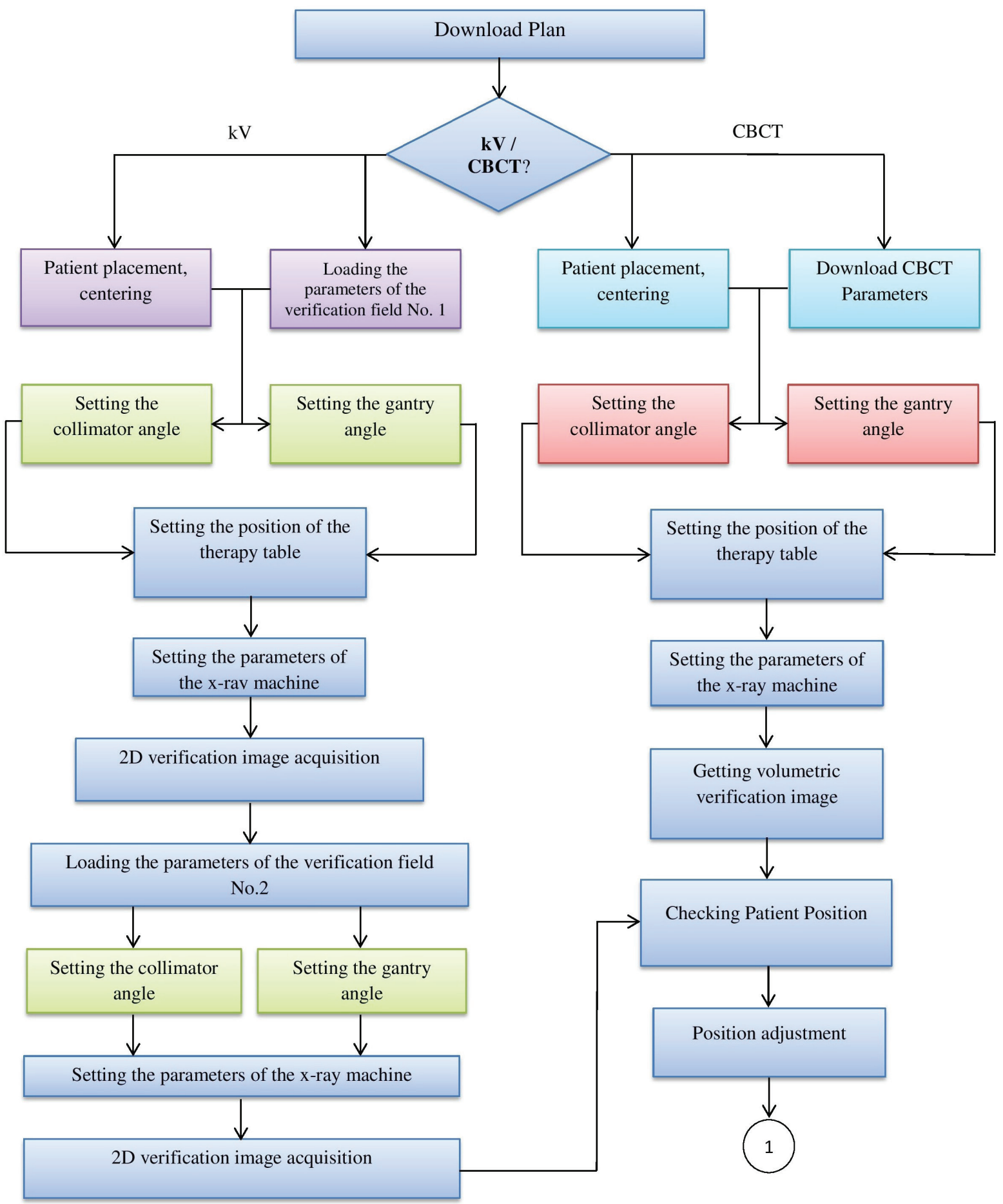




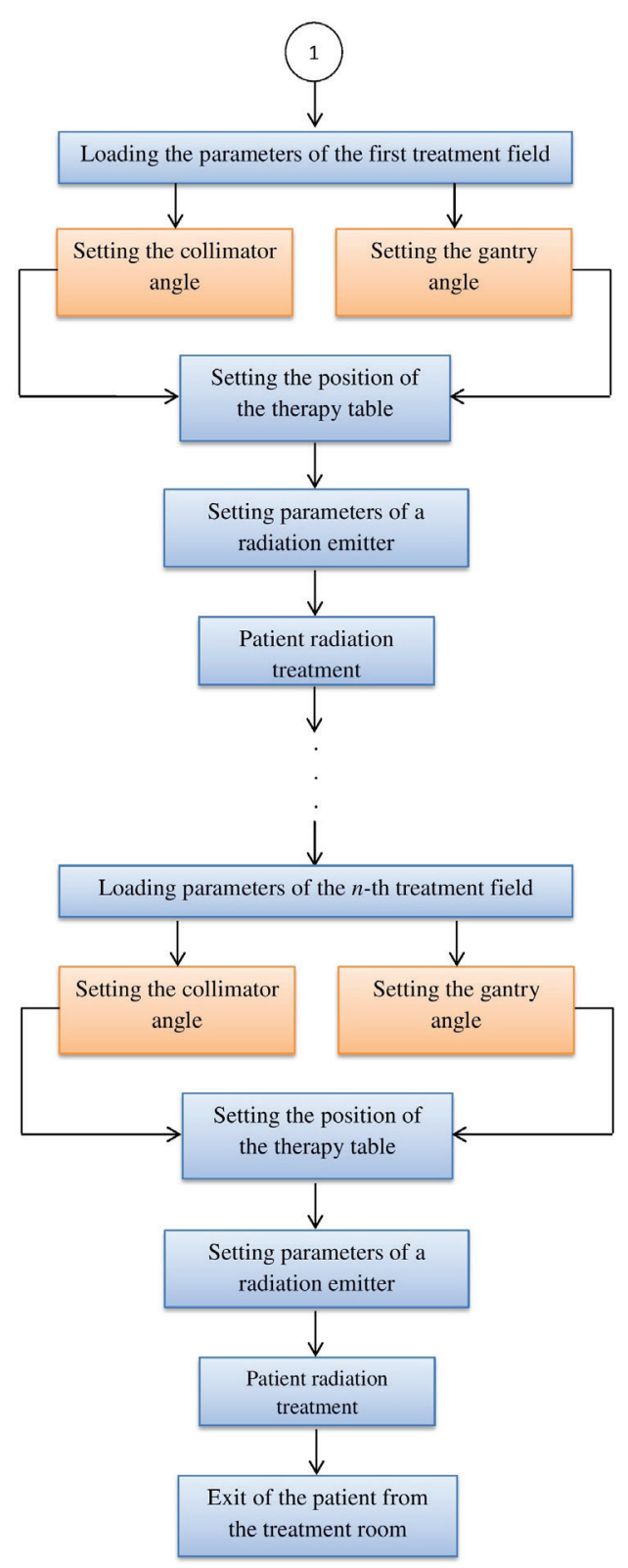

Figure 5-Flow diagram of a typical radiation therapy session

As seen in Figure 5, some of the RT session procedures run in parallel, which should be considered while defining its time at the stage of the patient dosimetric planning. Such procedures comprise a patient positioning and loading of the verification field or CBCT parameters, setting the collimator and beam arm angle values.

\section{Conclusion}

Experimental measurements of the irradiation session time parameters were taken for clinical cases of irradiation of patients with localizations of malignant neoplasms: prostate cancer, breast cancer, lung cancer, head and neck tumours (more than 2000 individual measurements for three different medical linear accelerators: "Clinac", "Unique", "Truebeam", as well as the gamma-therapeutic apparatus "Theratron".

The numerical values of the time spent for 3 groups of parameters of the irradiation session have been established: mechanical parameters of the radiation therapy apparatus, functional characteristics of the systems for the implementation of irradiation and parameters that directly depend on the personnel involved in the irradiation procedure; time dependences for mechanical parameters are constructed.

The flow diagram is proposed for the procedures of verifying the patient's position on the therapeutic table (two different techniques): the patient's previous radiation and the radiation therapy procedures themselves, which shows that a number of session components can run in parallel to each other, hence the time spent by the patient in the treatment room can be optimized.

Using the obtained values of the time spent on the implementation of various irradiation session components, it is possible to imbed the mathematical model that will determine in a preliminary manner the duration of the irradiation session at the stage of pre-irradiation preparation and choose the radiation therapy technique bearing in mind the individual parameters of the irradiation session in each specific clinical case.

\section{References}

1. Tarutin I.G., Titovich E.V. Primenenie lineinykh uskoriteley elektronov $v$ vysokotekhnologichnoi luchevoi terapii [The use of linear electron accelerators in hightech radiation therapy]. Minsk: Belarusskaya Navuka Publ., 2015,175 p.

2. International Commission On Radiation Units And Measurements. Determination of Absorbed Dose in a Patient Irradiated by Beams of X or Gamma rays in Radiotherapy Procedures. Washington, D.C., ICRU, 1976, rep. 24. DOI: 10.1093/jicru/ndh016

3. International Atomic Energy Agency. Design and Implementation of a radiotherapy programme: Clinical, medical physics, radiation protection and safety aspects. Vienna, IAEA, 1998, 97 p.

4. Titovich E.V., Patsiapalau P.A., Piatkevich M.N., Kiselev M.G. [The algorithm for determining timing of radiotherapy session components for different methods of 
oncology patients irradiation at the stage of radiotherapy planning]. Pribory $i$ metody izmerenii [Devices and Methods of Measurements]. 2017, vol. 8, no. 1, pp. 73-80 (in Russian). DOI: 10.21122/2220-9506-2017-8-1-73-80

5. Sibtain A., Morgan A., MacDougall N. Radiotherapy in Practice. Physics for Clinical Oncology. New York: Oxford University Press, 2012, 276 p.

6. Okeanov A.E. Rakv Belarusi: cifry i fakty. Analiz dannykh Belorusskogo kancer-registra za 2009-2018 gg. [Cancer in Belarus: figures and facts. Analysis of the data of the Belarusian Oncological Register for 2009-2018]. Minsk, Nacionalnaya biblioteka Belarusi, 2019, 422 p.
7. Xia Ping, Godley Andrew et al. (eds.) Strategies for radiation therapy treatment planning. Demos Medical Publishing, 2019, 319 p.

8. Khan F.M., Gibbons J.P. Khan's the physics of radiation therapy, 5th ed. Philadelphia: Wolters Kluwer, 2014, 584 p.

9. Podgorsak E.B. Radiation Physics for Medical Physicists, 2nd ed. Montreal: Springer, 2010, 759 p.

10. Dyk J.V. ACompendium for Medical Physicists and Radiation Oncologists: in 2 v. Madison: MPP, 2005, vol. 2: The modern Technology of Radiation Oncology, $491 \mathrm{p}$. 